\title{
Hyperoside and rutin of Nelumbo nucifera induce mitochondrial apoptosis through a caspase-dependent mechanism in HT-29 human colon cancer cells
}

\author{
TAE EUN GUON and HA SOOK CHUNG \\ Department of Food and Nutrition, College of Natural Sciences, Duksung Women's University, \\ Seoul 132-714, Republic of Korea
}

Received February 19, 2015; Accepted December 16, 2015

DOI: $10.3892 / \mathrm{ol} .2016 .4247$

\begin{abstract}
The present study demonstrates the mechanism of 2 flavonol glycosides, hyperoside and rutin, in the induction of apoptosis in HT-29 human colon cancer cells through the bioactivity-guided fractionation and isolation method. The chemical structure of hyperoside and rutin, isolated from the roots of Nelumbo nucifera, were established using extensive 1- and 2-dimensional nuclear magnetic resonance experiments and absolute high resolution fast-atom bombardment mass spectrometry, ultraviolet-visible and Fourier transform infrared spectroscopy spectral analytical methods. The treatment of HT-29 colon cancer cells with hyperoside and rutin significantly decreased cell viability in a dose-dependent manner. The concomitant activation of the mitochondria-dependent apoptotic pathway of hyperoside and rutin occurred via modulation of Bcl-2-associated X protein and B-cell lymphoma 2 expression, resulting in the activation of cleaved caspases-3, -8 and -9 and cleaved poly-(ADP-ribose) polymerase. The findings of the present study indicate that hyperoside and rutin induce apoptosis in HT-29 human colon cancer cells, and that this phenomenon is mediated via the death receptor-mediated and mitochondria-mediated apoptotic pathways. These results suggest that hyperoside and rutin may be useful in the development of a colon cancer therapy protocol.
\end{abstract}

\section{Introduction}

Colorectal cancer is the second most prevalent malignancy and the leading cause of cancer-associated mortality worldwide (1). The incidence rates of colorectal cancer have been rapidly increasing in Asia due to smoking, the increased tendency for

Correspondence to: Professor Ha Sook Chung, Department of Food and Nutrition, College of Natural Sciences, Duksung Women's University, 33 Samyang Road, Seoul 132-714, Republic of Korea E-mail: hasook@duksung.ac.kr

Key words: Nelumbo nucifera, flavonol glycosides, hyperoside, rutin, HT-29, apoptosis being overweight and the excessive consumption of meat and alcohol $(2,3)$. Multiple phytochemicals have been identified through epidemiological studies as potential cancer-fighting agents that may be obtained from commonly consumed fruits and vegetables $(4,5)$.

Although the toxicity of chemotherapy is a major obstacle for the successful treatment of cancer, chemo and radiation therapies are the major tools for cancer treatment, at present. For these reasons, the identification of safe components with a high selectivity for killing cancer cells from natural sources is required $(6,7)$. Certain secondary metabolites from natural plants exhibit biological activities, which are considered to be critical for maintaining human health. The development of high quality varieties that contain increased levels of bioactive components may improve the medicinal value of plants (8).

Nelumbo nucifera, the lotus, is an aquatic perennial plant that is commonly cultivated in water gardens in tropical Asia and Australia (9). The flowers, seeds, young leaves, rhizomes and roots of $N$. nucifera are used for edible and medicinal sources in Asian regions. The roots of $N$. nucifera have been identified as being rich in dietary fiber, vitamins B1, B2, B6 and $\mathrm{C}$, potassium, phosphorus, copper and manganese (10). $N$. nucifera contains biologically effective flavonoids, including kaempferol, quercetin, rutin and hyperoside, exhibits anti-inflammatory, -oxidant, -fungal, -microbial and tyrosinase inhibitory activities, and has protective properties in carbon tetrachloride-induced liver damage (11-18).

In a previous report, the anti-proliferative effect of a $70 \%$ ethanol extract of the root of $N$. nucifera on HT-29 human colon cancer cells was investigated, which was based on cell viability, Hoechst 33342 nuclear staining, apoptosis analysis, western blotting and reverse transcription-polymerase chain reaction (RT-PCR) analyses. $N$. nucifera was indicated to inhibit the growth of colon cancer cells by the activation of the mitochondria-dependent apoptotic pathway via the modulation of Bcl-2-associated X protein (Bax) and B-cell lymphoma 2 (Bcl-2) expression (19).

Flavonoids are polyphenol compounds that are commonly identified in plants and have gained considerable interest and attention in recent years, due to the bioactive functions they possess. Among these flavanoids, hyperoside and rutin are composed of flavan-3-ol glycosidic linkages, which are 
molecules of joined together glucose and glucose and rhamnose, respectively (Fig. 1). Despite evidence for the numerous biological effects of flavan-3-ols, the anti-cancer effects of hyperoside and rutin-induced apoptosis have not been investigated.

Numerous previous studies aimed to identify anticancer components from natural sources (20-23). Therefore, the effects of hyperoside and rutin on the proliferation and apoptosis in HT-29 human colon cancer cells, through activity-guided fractionation and isolation methods, are investigated in the present study.

\section{Materials and methods}

Chemicals and reagents. Propidium iodide (PI) and 3-(4,5-dimethylthiazol-2-yl)-2,5-diphenyltetrazolium bromide (MTT) were purchased from Merck Millipore (Darmstadt, Germany) and Sigma-Aldrich(St.Louis,MO,USA), respectively. Primary antibodies included anti-mouse $\beta$-actin (sc-47778), and rabbit monoclonal anti-Bcl-2 (sc-492) and anti-Bax (sc-493) (dilution, 1:1,000; Santa Cruz Biotechnology, Inc., Dallas, TX, USA), and were purchased from Santa Cruz Biotechnology, Inc. (Dallas, TX, USA). Rabbit monoclonal antibodies against cysteinyl aspartate-specific cleaved caspase-3 (9661), -8 (8592) and -9 (7237) and poly-(ADP-ribose) polymerase (PARP; 5625) antibodies were purchased from Cell Signaling Technologies, Inc. (Danvers, MA, USA). Secondary antibodies included goat anti-rabbit IgG-horseradish peroxidase (HRP; sc-2004) and goat anti-mouse IgG-HRP (sc-2005) (dilution, 1:2,000), and were purchased from Santa Cruz Biotechnology, Inc. (Dallas, TX, USA). All other chemicals and reagents were of the highest analytical grade.

Plant materials. The roots of $N$. nucifera were purchased at Nonghyup Hanaro mart (Yangjae, Seoul, Korea) in May 2012 (19). Roots were dried using an automatic food dryer (LD-528WG; L'equip Co., Ltd., Seoul, Korea) and then were ground to fine powders.

Instrumental analysis. The uncorrected melting points (MPs) were determined using Mitamura-Riken Kogyo MEL-TEMP apparatus (Mitamura Riken Kogyo Inc., Tokyo, Japan). Ultraviolet-visible (UV-Vis) spectra were obtained using a JP/U3010 spectrometer (Hitachi, Ltd.,Tokyo, Japan) and infrared (IR) spectra were obtained on a FT/IR-5300 spectrometer (Jasco International Co., Ltd., Tokyo, Japan). The electron ionization (EI) and fast-atom bombardment-mass spectrometry (FAB-MS) spectra were obtained on a JMS-700 spectrometer (JEOL, Ltd., Tokyo, Japan). The nuclear magnetic resonance (NMR) spectra were measured on an Avance-500 spectrometer (500 MHz; Bruker Corporation, Billerica, MA, USA), and the chemical shifts were referenced against tetramethylsilane (TMS) and deuterium dimethylsulfoxide (DMSO-d6) as NMR solvents. Column chromatography (CC) was run on a silica gel 60 (70-230 or 230-400 mesh; Merck Millipore) and Sephadex LH-20 (25-100 mm; GE Healthcare Life Sciences, Uppsala, Sweden). Thin layer chromatography (TLC) was performed on silica gel 60F254 and RP-18254S plates. TLC plates were visualized using UV light, stained with $\mathrm{FeCl}_{3}$, aniline hydrogen phthalate and $20 \%$ $\mathrm{H}_{2} \mathrm{SO}_{4}$ and then heated at $70-80^{\circ} \mathrm{C}$ for 5 sec.<smiles>O=c1c(OC2OC3C(O)C(O)C(O)C(O)C3O2)c(-c2ccc(O)c(O)c2)oc2cc(O)cc(O)c12</smiles>

B

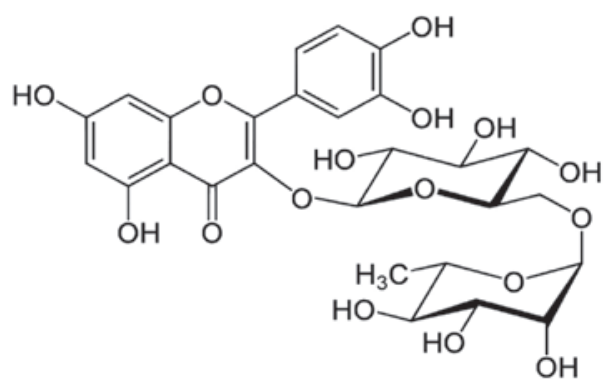

Figure 1. Chemical structure of (A) hyperoside and (B) rutin.

Extraction and isolation of compounds. The dried powdered roots of $N$. nucifera $(800 \mathrm{~g})$ were extracted 3 times using $70 \%$ ethyl alcohol $(\mathrm{EtOH})$ under $70-80^{\circ} \mathrm{C}$ reflux conditions to produce $92 \mathrm{~g}$ extracts. The $70 \% \mathrm{EtOH}$ extract was suspended in water and successively partitioned with $\mathrm{n}$-hexane, dichloromethane $\left(\mathrm{CH}_{2} \mathrm{C}_{12}\right)$, ethyl acetate (EtOAc) and n-butanol $(\mathrm{n}-\mathrm{BuOH})$ to yield solvent-soluble fractions. A 12-g portion of the EtOAc fraction was subjected to silica gel $\mathrm{CC}$ and eluted with $\mathrm{CH}_{2} \mathrm{C}_{12}$-methanol $(\mathrm{MeOH})$ mixtures with increasing concentrations of $\mathrm{MeOH}(0,20,50,70$ and 100\%) to produce 12 fractions (E-01-E12). Fraction E-08 was submitted to silica gel $\mathrm{CC}$ using $\mathrm{CH}_{2} \mathrm{C}_{12}-\mathrm{MeOH}$, in the ratios of 1:9, 1:7, 1:5 and 1:2, to yield fifteen sub-fractions. The sub-fractions E-08-8 (110 mg) and E-08-11 $(180 \mathrm{mg})$ were successively purified using Sepadex LH-20 CC and vacuum liquid chromatography (VLC) with $\mathrm{MeOH}$ to produce hyperoside $(28 \mathrm{mg})$ and rutin $(34 \mathrm{mg})$.

Cell culture. The human colon cancer HT-29 cell line was obtained from the Korean Cell Line Bank (Seoul, Korea). The normal colon epithelium FHC cell line was obtained from the American Type Culture Collection (Manassas, VA, USA). HT-29 cells were maintained in Roswell Park Memorial Institute (RPMI)-1640 medium, supplemented with 10\% Invitrogen fetal bovine serum (FBS; Thermo Fisher Scientific, Inc., Waltham, MA, USA), 100 units/ml penicillin and $100 \mu \mathrm{g} / \mathrm{ml}$ streptomycin (Gibco; Thermo Fisher Scientific, Inc.). FHC cells were maintained in Dulbecco's modified Eagle medium nutrient mixture F-12 (DMEM)/F-12, which contained $10 \mathrm{ng} / \mathrm{ml}$ cholera toxin, $0.005 \mathrm{mg} / \mathrm{ml}$ insulin, $0.005 \mathrm{mg} / \mathrm{ml}$ transferrin, $100 \mathrm{ng} / \mathrm{ml}$ hydrocortisone, supplemented with $10 \%$ FBS, 100 units $/ \mathrm{ml}$ penicillin and $100 \mu \mathrm{g} / \mathrm{ml}$ streptomycin. All of the cell lines were cultured in a humidified chamber with $5 \%$ $\mathrm{CO}_{2}$ at $37^{\circ} \mathrm{C}$. Cell counts were performed using a hemocytometer from Hausser Scientific (Horsham, PA, USA).

Cell viability assay. The cytotoxic effects of hyperoside and rutin on the HT-29 and FHC cell lines were estimated 
colorimetrically using the MTT method, which is based on the reduction of tetrazolium salt by mitochondrial dehydrogenase in viable cells (24). Briefly, the cells were seeded in a 96-well plate (density, $1 \times 10^{4}$ cells $/ \mathrm{ml}$ ) and were then treated with hyperoside and rutin at final concentrations of 0,100 and $200 \mu \mathrm{m}$. Subsequent to $24 \mathrm{~h}$ incubation, MTT solution was added to each well at a final concentration of $0.4 \mathrm{mg} / \mathrm{ml}$. Subsequent to $2 \mathrm{~h}$ of incubation, the supernatants were aspirated and replaced with $150 \mu \mathrm{l}$ of dimethyl sulfoxide (DMSO) to dissolve the formazan product. The absorbance at $570 \mathrm{~nm}$ was then read using a spectrophotometric plate reader (model 550; Bio-Rad Laboratories, Inc., Hercules, CA, USA). The results were calculated as percentages of the unexposed control.

Nuclear staining with Hoechst 33342. The nuclear morphology of the cells was observed using Hoechst 33342 DNA-specific blue fluorescent dye. The viable cells were stained homogeneously, whereas the apoptotic cells that had undergone chromatin condensation or nuclear fragmentation were not stained (25). The HT-29 cells were treated with hyperoside and rutin at the various concentrations. Cells were then fixed for $30 \mathrm{~min}$ at $37^{\circ} \mathrm{C}$ in $100 \% \mathrm{MeOH}$, washed with PBS, and stained with $2 \mu \mathrm{g} / \mathrm{ml}$ Hoechst 33342 (Sigma-Aldrich). The cells were observed under a BX51 fluorescence microscope and images were captured with a DP70 camera (Olympus Corporation, Tokyo, Japan).

Apoptosis analysis. An Annexin V/PI double staining assay was carried out in order to distinguish between the early and late apoptosis stages. The stages were determined using an ApoScan $^{\mathrm{TM}}$ Annexin V-FITC apoptosis detection kit (BioBud, Seoul, Korea) in hyperoside and rutin-treated HT-29 cells. The cells were trypsinized, harvested and washed with PBS. The cells were resuspended in $1 \mathrm{X}$ binding buffer $(500 \mu \mathrm{l})$ and incubated with $1.25 \mu \mathrm{l}$ of Annexin V-fluorescein isothiocyanate (concentration, $200 \mu \mathrm{g} / \mathrm{ml}$ ) at room temperature for $15 \mathrm{~min}$. The supernatant was then removed following centrifugation at $400 \mathrm{x} \mathrm{g}$ for $10 \mathrm{~min}$. The cells were resuspended in $500 \mu \mathrm{l}$ of $1 \mathrm{X}$ binding buffer and the cell suspensions were then stained with $10 \mu \mathrm{l} \mathrm{PI}$ (concentration, $30 \mu \mathrm{g} / \mathrm{ml}$ ) at $4^{\circ} \mathrm{C}$ in the dark. Fluorescence was quantified using FACSCalibur flow cytometry (BD Biosciences, Franklin Lakes, NJ, USA). The levels of early and late apoptosis were determined as the percentage of Annexin $\mathrm{V}^{+} / \mathrm{PI}^{-}$or Annexin $\mathrm{V}^{+} / \mathrm{PI}^{+}$cells, respectively.

Western blot analysis. Western blot analyses were performed, as previously described (20). The cells were cultured, harvested and lysed on ice for $30 \mathrm{~min}$ in lysis buffer $(120 \mathrm{mM} \mathrm{NaCl}$; $40 \mathrm{mM}$ Tris, $\mathrm{pH} 8.0 ; 0.1 \%$ nonyl phenoxypolyethoxylethanol) and were then centrifuged at $13,000 \mathrm{x}$ for $15 \mathrm{~min}$. Lysates from each sample were mixed with $5 \mathrm{X}$ sample buffer [0.375 M Tris- $\mathrm{HCl} ; 5 \%$ sodium dodecyl sulfate (SDS); 5\% $\beta$-mercaptoethanol; $50 \%$ glycerol; $0.05 \%$ bromophenol blue, $\mathrm{pH}$ 6.8] and were then heated to $95^{\circ} \mathrm{C}$ for $5 \mathrm{~min}$. Equal amounts of protein were separated by $12 \%$ SDS-polyacrylamide gel electrophoresis (SDS-PAGE) and were transferred onto a nitrocellulose membrane. The membranes were then washed with Tris-buffered saline (10 mM Tris, $150 \mathrm{mM} \mathrm{NaCl})$ containing $0.05 \%$ Tween-20 (TBST), and were then blocked in TBST containing $5 \%$ nonfat dried milk. The membranes were incubated with respective specific primary antibodies overnight at $4^{\circ} \mathrm{C}$. Subsequent to 3 washes in TBST, the membranes were incubated with the appropriate secondary antibodies coupled to HRP for $1 \mathrm{~h}$ at room temperature. The membranes were then washed 3 times in TBST with 15 min between each step, and protein detection was performed using an enhanced chemiluminescence western blotting detection kit. The data of specific protein levels are presented as multiples relative to the control.

$R T-P C R$. Cells were treated with dihydroxyflavone at $10 \mu \mathrm{g} / \mathrm{ml}$ for various lengths of time, and were treated with hyperoside and rutin at final concentrations of 0,100 and $200 \mu \mathrm{m}$. Total RNA was isolated from the cells using Gibco TRIzol ${ }^{\circledR}$ reagent (Thermo Fisher Scientific, Inc.), according to the manufacturer's protocol, and quantitated using spectrophotometry. Total RNA $(5 \mu \mathrm{g})$ was reverse transcribed into cDNA by incubating with Invitrogen SuperScript ${ }^{\circledR T M}$ RNase H reverse transcriptase (Thermo Fisher Scientific, Inc.). PCR was conducted in a reaction composed of $40 \mu \mathrm{g}$ of $1.25 \mathrm{X}$ reacting mix, $1 \mu \mathrm{l}$ enzyme mix, $1 \mu \mathrm{l}$ forward primer $(200 \mathrm{nM}), 1 \mu 1$ reverse primer $(200 \mathrm{nM})$ and RNA. cDNA was performed with following conditions: cDNA synthesis at $45^{\circ} \mathrm{C}$ for $30 \mathrm{~min}$, followed by denaturation at $94^{\circ} \mathrm{C}$ for $2 \mathrm{~min}$. A total of 40 cycles of PCR amplification were then performed with following conditions: $94^{\circ} \mathrm{C}$ for $15 \mathrm{sec}, 60^{\circ} \mathrm{C}$ for $30 \mathrm{sec}$, and $68^{\circ} \mathrm{C}$ for $1 \mathrm{~min}$. The last cycle was followed by final extension step at $72^{\circ} \mathrm{C}$ for $5 \mathrm{~min}$.

The primer pairs (Bionics, Seoul, Korea), forward and reverse, respectively, were as follows: $\beta$-actin, 5'-CCTCTA TGCCAACACAGTGC-3' and 5'-ATACTCCTGCTTGCT GATCC-3'; Bcl-2, 5'-AGCTGCACCTGACGCCCTTCA-3' and 5'-AGCCAGGAGAAATCACAGAGG-3'; Bax,5'-ATGGAC GGGTCCGGGGAGCAG-3' and 5'-CAGTTGAAGTTGCCG TCAGA-3'. PCR was performed for 40 cycles. Temperature cycling was initiated with each cycle, using the Takara PCR Thermal Cycler Dice (Takara Bio, Inc., Otsu, Japan), as follows: $\beta$-actin, $98^{\circ} \mathrm{C}$ for $10 \mathrm{sec}$ (denaturation), $55^{\circ} \mathrm{C}$ for $30 \mathrm{sec}$ (annealing), $72^{\circ} \mathrm{C}$ for $1 \mathrm{~min}$ (extension); $\mathrm{Bcl}-2,98^{\circ} \mathrm{C}$ for $10 \mathrm{sec}$, $60^{\circ} \mathrm{C}$ for $30 \mathrm{sec}, 72^{\circ} \mathrm{C}$ for $1 \mathrm{~min}$; Bax, $98^{\circ} \mathrm{C}$ for $10 \mathrm{sec}, 60.5^{\circ} \mathrm{C}$ for $30 \mathrm{sec}$ and $72^{\circ} \mathrm{C}$ for $1 \mathrm{~min}$. The amplified products were resolved on $1 \%$ agarose gels, stained with ethidium bromide (Sigma-Aldrich) and photographed under ultraviolet light using a Mini BIS image analysis system (DNR Bio-Imaging Systems Ltd., Jerusalem, Israel).

Statistical analyses. SPSS software version 22.0 (IBM SPSS, Armonk, NY, USA) was used to analyse the data. The results were subjected to analysis of variance, followed by the Tukey range test in order to analyze the differences between conditions. In each case, the $\mathrm{P}<0.05$ was considered to indicate a statistically significant difference. All measurements were made in triplicate, and all values are given as the mean \pm standard deviation.

\section{Results}

Isolation of pure compounds. The dried and ground compounds of the root of N. nucifera were extracted with $70 \%$ $\mathrm{EtOH}$ and successively fractionated using n-hexane, $\mathrm{CH}_{2} \mathrm{C}_{12}$, EtOAc and $n-\mathrm{BuOH}$ to identify the cytotoxic solvent-soluble fractions of the HT-29 human colon cancer cell line, through 

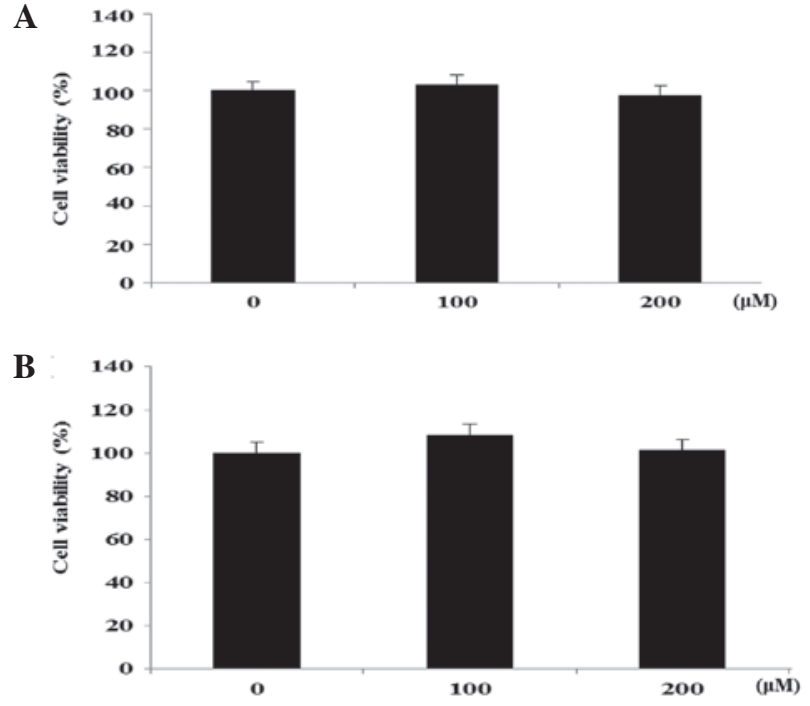

Figure 2. Cytotoxic effect of (A) hyperoside and (B) rutin on normal human colon cells. Cell viability at the indicated concentrations of hyperoside and rutin in human normal colon cells from the FHC cell line was assessed at $24 \mathrm{~h}$, using 3-(4,5-dimethylthiazol-2-yl)-2,5-diphenyltetrazolium bromide assays.

the activity-guided fractionation and isolation method (26) Of the fractions, the EtOAc-soluble fraction of $N$. nucifera demonstrated a strong cytotoxicity with an half maximal inhibitory concentration value of $26.7 \pm 0.8 \mu \mathrm{g} / \mathrm{ml}$ (data not shown), based on the cell viability assay. CC was applied to the EtOAc-soluble fraction for the isolation of pure compounds. The chemical structures of the pure compounds were characterized as hyperoside and rutin based on physicochemical methods, co-TLC, MP, FAB-MS, UV-Vis, FT-IR, and proton (1H)- and ${ }^{13} \mathrm{C}$-NMR spectral data (Fig. 1).

Spectral data of hyperoside. The spectral data were as follows: Pale yellowish powder $(\mathrm{MeOH}) ; \mathrm{FeCl}_{3}$ and aniline hydrogen phthalate color reaction, positive; $\mathrm{MP}, 197-202^{\circ} \mathrm{C}$; UV $(\mathrm{MeOH})$ $\lambda_{\max }, 280$ (4.54), 364 (4.36) nm; IR $v_{\max }(\mathrm{KBr}), \mathrm{cm}^{-1}: 3,380(\mathrm{OH})$, 1,660 ( $\alpha, \beta$-unsaturated $\mathrm{C}=\mathrm{O}), 1,612,1,490$ (aromatic $\mathrm{C}=\mathrm{C})$, 1,240 (aromatic C-O), 1,062 and 1,012 (glycosidic C-O); FAB-MS, $465\left[\mathrm{M}^{+} \mathrm{H}\right]^{+} \mathrm{m} / \mathrm{z}$; 1H-NMR (500 MHz, DMSO-d $)_{6}$ ): $\delta 8.27(1 \mathrm{H}, \mathrm{s}, 5-\mathrm{OH}), 7.66(1 \mathrm{H}, \mathrm{dd}, J=2.1,8.4, \mathrm{H}-6), 7.56(1 \mathrm{H}$, $\left.\mathrm{d}, J=2.1, \mathrm{H}-2^{\prime}\right), 6.82(1 \mathrm{H}, \mathrm{d}, J=8.4), 6.43(1 \mathrm{H}, \mathrm{d}, J=1.9, \mathrm{H}-8)$, $6.22(1 \mathrm{H}, \mathrm{d}, J=1.9, \mathrm{H}-6)$ and $5.36(1 \mathrm{H}, \mathrm{d}, J=7.6$, anomeric proton); ${ }^{13} \mathrm{C}-\mathrm{NMR}\left(125 \mathrm{MHz}, \mathrm{DMSO}-\mathrm{d}_{6}\right)$ : $\delta 181.4(\mathrm{C}-4), 164.4(\mathrm{C}-2)$, 162.4 (C-7), 161.0 (C-5), 160.1 (C-7), 156.6 (C-9), 150.2 (C-4'), 145.2 (C-3'), 121.2 (C-1'), 119.1 (C-6'), 116.1 (C-5'), 113.2 (C-2'), 105.1 (C-10), 103.1 (C-3), 99.1 (C-8), 97.7 (Glc-1"), 77.0 (Glc-5"), 76.7 (Glc-2"), 76.1 (Glc-3"), 70.1 (Glc-4") and 60.4 (Glc-6").

Spectral data of rutin. The spectral data were as follows: Pale yellowish powder $(\mathrm{MeOH}) ; \mathrm{FeCl}_{3}$ and aniline hydrogen phthalate color reaction, positive; $\mathrm{MP}, 202-204^{\circ} \mathrm{C}$; UV $\lambda_{\max }(\mathrm{MeOH})$, 268 (4.50), 375 (4.26) nm; IR $\mathrm{v}_{\max }(\mathrm{KBr}), \mathrm{cm}^{-1}: 3,360(\mathrm{OH})$, 1,670 ( $\alpha, \beta$-unsaturated $\mathrm{C}=\mathrm{O}), 1,600,1,512($ aromatic $\mathrm{C}=\mathrm{C})$, 1,240 (aromatic C-O), 1,060 and 1,015 (glycosidic C-O); FAB-MS, $611\left[\mathrm{M}^{+} \mathrm{H}\right]^{+} \mathrm{m} / \mathrm{z}$; 1H-NMR (500 MHz, DMSO-d 6 ): $\delta 7.68\left(1 \mathrm{H}, \mathrm{d}, J=2.1, \mathrm{H}-2^{\prime}\right), 7.54\left(1 \mathrm{H}, \mathrm{dd}, J=2.1,8.4, \mathrm{H}-6^{\prime}\right)$, $6.85\left(1 \mathrm{H}, \mathrm{d}, J=8.4, \mathrm{H}-5^{\prime}\right), 6.40(1 \mathrm{H}, \mathrm{d}, J=1.8, \mathrm{H}-8), 6.18(1 \mathrm{H}$,
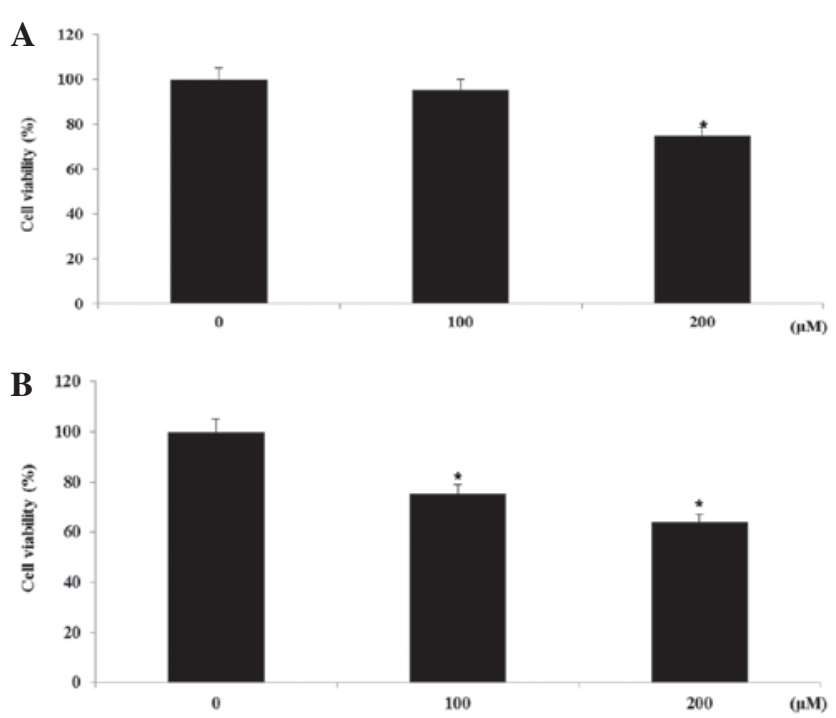

Figure 3. Cytotoxic effect of (A) hyperoside and (B) rutin on HT-29 human colon cancer cells. Cell viability at the indicated concentrations of hyperoside and rutin on human colon adenocarcinoma cells from the HT-29 cell line was assessed at $24 \mathrm{~h}$, using 3-(4,5-dimethylthiazol-2-yl)-2,5-diphenyltetrazolium bromide assays. ${ }^{*} \mathrm{P}<0.05$ vs. control cells.

$\mathrm{d}, J=1.8, \mathrm{H}-6), 5.31(1 \mathrm{H}, \mathrm{d}, J=7.6$, anomeric proton) and 0.92 (3H, d, J=5.5, Rha-6); ${ }^{13} \mathrm{C}-\mathrm{NMR}\left(125 \mathrm{MHz}, \mathrm{DMSO}-\mathrm{d}_{6}\right)$,

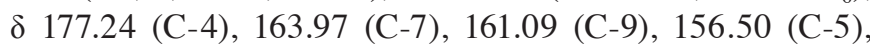
156.30 (C-2), 148.29 (C-4'), $144.63(\mathrm{C}-3$ '), 133.16 (C-3), 121.48 (C-6'), $121.05\left(\mathrm{C}-1^{\prime}\right), 116.15\left(\mathrm{C}^{\prime} 5^{\prime}\right), 115.11\left(\mathrm{C}-2^{\prime}\right)$, 103.83 (C-10), 101.04 (C-Glc"), 100.64 (C-Rha"), 98.58 (C-6), 93.49 (C-8), 76.30 (Rha-5"), 75.77 (Glc-5"), 73.95 (Glc-2"), 71.70 (Rha-4"), 70.43 (Rha-3"), 70.25 (Rha-2"), 69.86 (Glc-4"), 68.14 (Rha-5"), 66.89 (Glc-6") and 17.63 (Rha-6").

Cell viability in FHC and HT-29 cell lines. In the preliminary investigation, the EtOAc-soluble fractions of the roots of $N$. nucifera were observed to exhibit significant cytotoxicity on the HT-29 human colon cancer cells $\left(\mathrm{IC}_{50}, 26.7 \pm 0.8 \mu \mathrm{g} / \mathrm{ml}\right)$. A bioactivity-guided isolation of the cytotoxic EtOAc-soluble fraction on HT-29 human colon cancer cells was performed, leading to the isolation of 2 flavonol glycosides, hyperoside and rutin. The effects of hyperoside and rutin on the growth of FHC human colon normal cells and HT-29 human colon cancer cells was examined using an MTT assay. The cells were exposed to various concentrations $(0-200 \mu \mathrm{m})$ of the flavanoids for $24 \mathrm{~h}$, and the cytotoxicity was determined as a percentage of the viable treated cells in comparison with the number of viable untreated control cells. As shown in Fig. 2, hyperoside and rutin did not affect the proliferation on FHC colon normal cells in a dose-dependent manner. However, hyperoside and rutin significantly inhibited the proliferation of HT-29 human colon cancer cells in a dose-dependent manner. Subsequent to $24 \mathrm{~h}$ of exposure, hyperoside and rutin induced 25.6 and $37.1 \%$ growth inhibition at the concentration of $200 \mu \mathrm{m}$, respectively (Fig. 3). Therefore, hyperoside and rutin were selected for the subsequent experiments from the flavonoids isolated from $N$. nucifera.

Induction of apoptosis in HT-29 cells. The apoptogenic properties of the compounds were investigated through morphological changes in HT-29 cells. Nuclear Hoechst 33342 staining was 
A
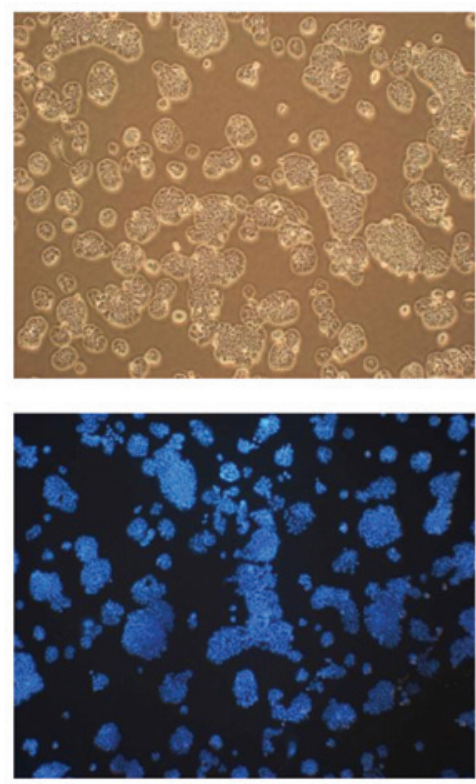

0
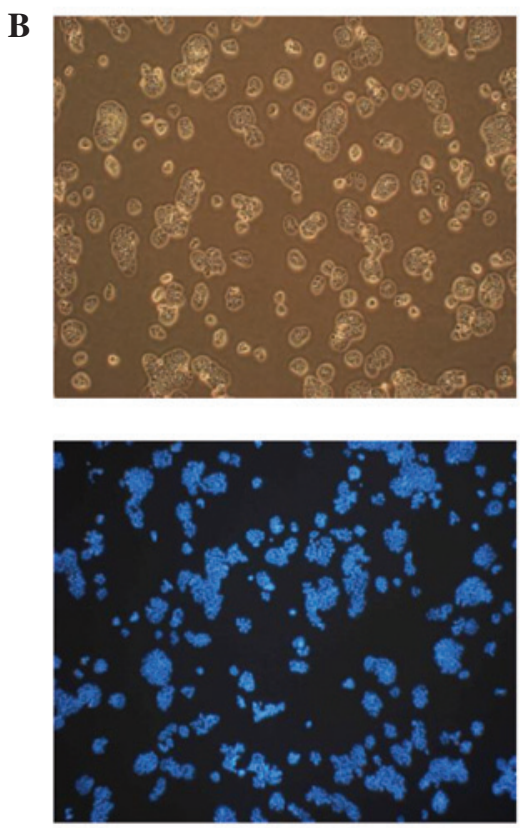

0
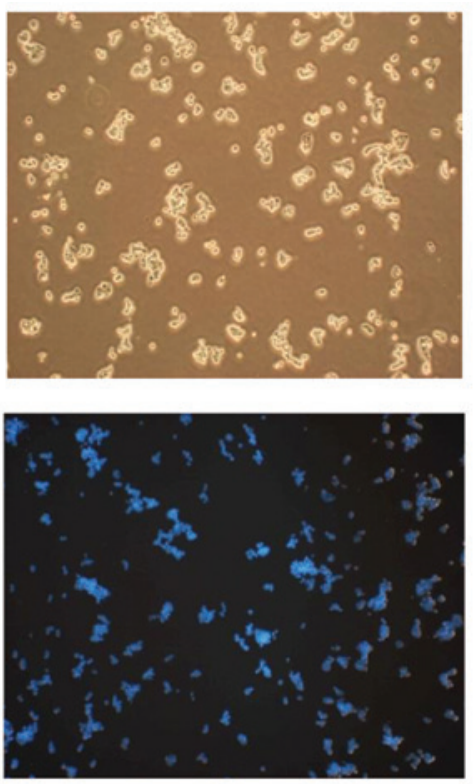

100
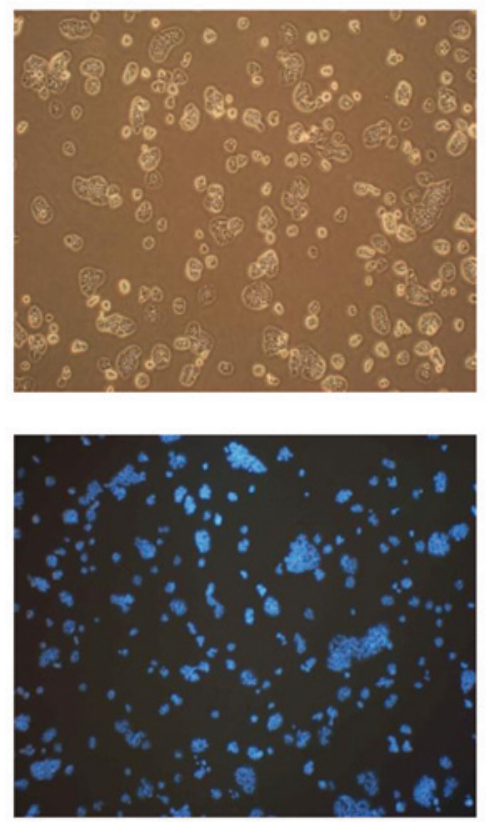

100
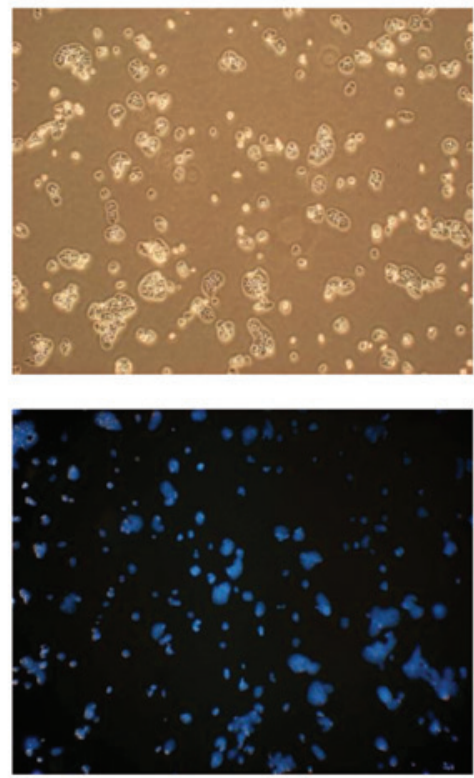

200
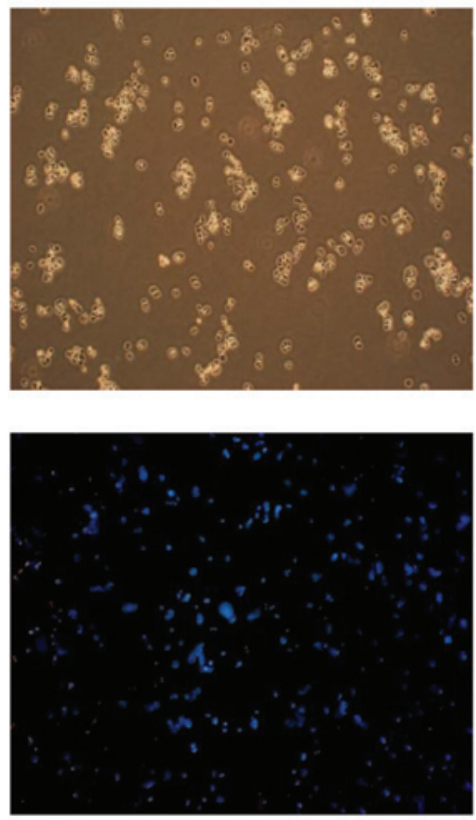

200

Figure 4. Induction of apoptosis by (A) hyperoside and (B) rutin on HT-29 human colon cancer cells. The formation of apoptotic bodies in Hoechst 33342-stained cells were observed using fluorescent microscopy (magnification, $\mathrm{x} 400$ ).

performed in order to determine whether the anti-proliferative effect of hyperoside and rutin was due to apoptosis. As shown in Fig. 4, HT-29 cells that were treated with hyperoside and rutin exhibited a number of morphological changes, including cell shrinkage, condensed chromatin, rounding, blebbing and an increased density of apoptotic bodies compared with the untreated control cells. The number of apoptotic cells increased in a dose-dependent fashion.

Effects on apoptosis in HT-29 cells. In order to quantify the percentage of apoptotic cells, flow cytometry analysis was performed using double staining with Annexin V and PI. The Annexin V/PI' population was considered to account for unaffected cells, the Annexin $\mathrm{V}^{+} / \mathrm{PI}^{-}$population for early apoptosis, Annexin $\mathrm{V}^{+} / \mathrm{PI}^{+}$for late apoptosis and Annexin $\mathrm{V}^{-} / \mathrm{PI}^{+}$for necrosis. The results showed that the treatment of the cells with hyperoside and rutin significantly increased the percentage of apoptotic cells compared with untreated control cells (Fig. 5). The total apoptotic cell populations of hyperoside and rutin were increased by 52.4 and $56.5 \%$ at $200 \mu \mathrm{m}$, respectively, compared with the control. These results indicate that hyperosde and rutin may induce apoptosis in HT-29 human colon cancer cells.

Effects on Bcl-2 and Bax expression. In order to study the effects of hyperoside and rutin on apoptosis in HT-29 cells, the expression levels of apoptosis regulatory proteins, including 
A

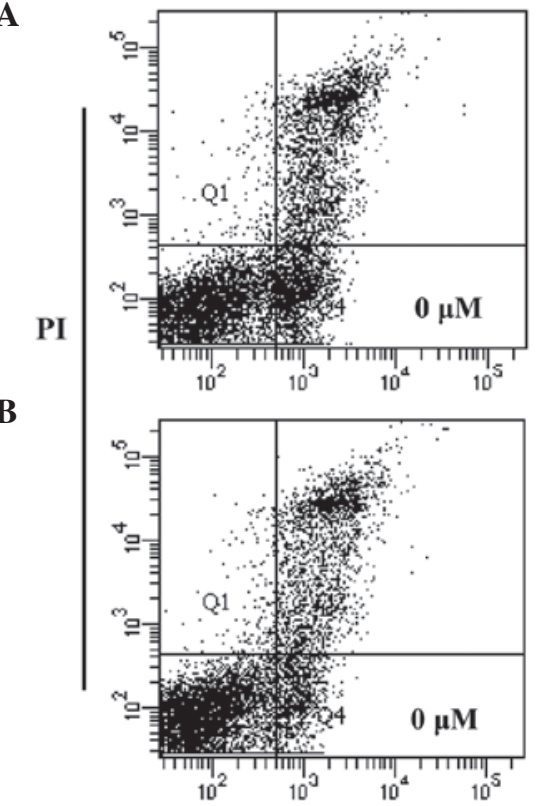

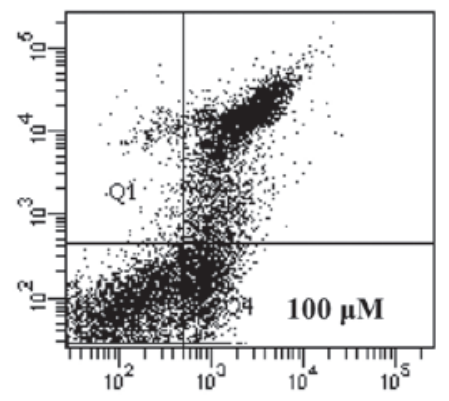

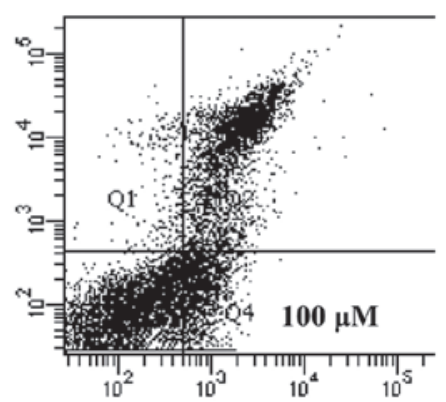

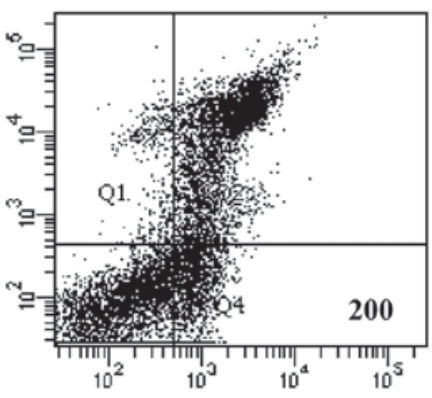

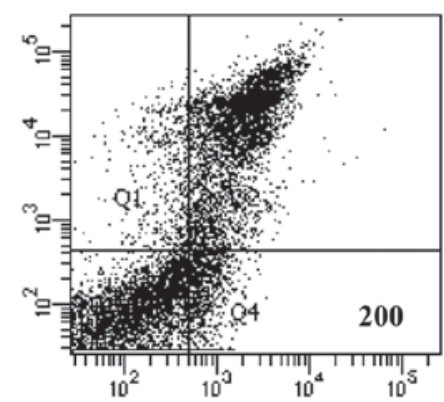

Annexin V-FITC

Figure 5. Induction of apoptosis by (A) hyperoside and (B) rutin on HT-29 human colon cancer cells. Flow cytometric analysis was performed on HT-29 human colon cancer cells that were incubated with hyperoside and rutin for $24 \mathrm{~h}$. The right bottom quadrant represents Annexin V-stained cells (early-phase apoptotic cells). The top right quadrant represents PI - and Annexin V-stained cells (late-phase apoptotic cells). Bcl-2, B-cell lymphoma 2; Bax, Bcl-2-associated X protein.

A

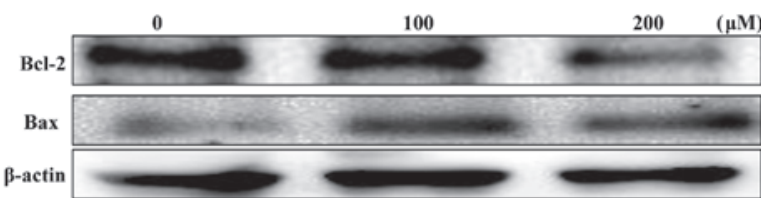

B

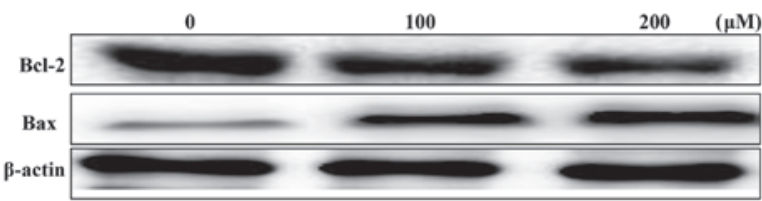

C

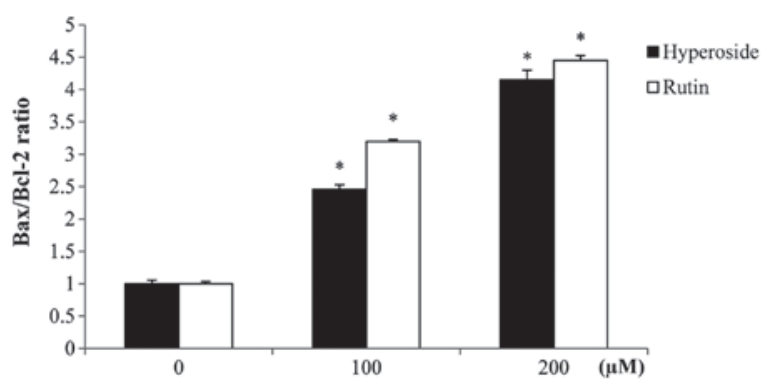

Figure 6. Effect of (A) hyperoside and (B) rutin on the expression of apoptosis-associated proteins on HT-29 human colon cancer cells. Cell lysates were electrophoresed and $\mathrm{Bax}$ and $\mathrm{Bcl}-2$ were detected using western blot analysis. (C) Statistical analysis of apoptosis. Bcl-2, B-cell lymphoma 2; Bax, Bcl-2-associated $\mathrm{X}$ protein. ${ }^{*} \mathrm{P}<0.05$ vs. control cells.

Bcl-2 and Bax were examined. The mitochondrial pathway is an important apoptosis pathway as it regulates the apoptotic cascade via a convergence of signaling at the mitochondria. Bcl-2 interacts with the mitochondrial plasma membrane and prevents mitochondrial membrane pores from opening during
A

Cleaved caspase-8

Cleaved caspase- 9

Cleaved PARP

$\beta$-actin

B

Cleaved caspase-9

Cleaved caspase- 3

Cleaved PARP

$\beta$-actin
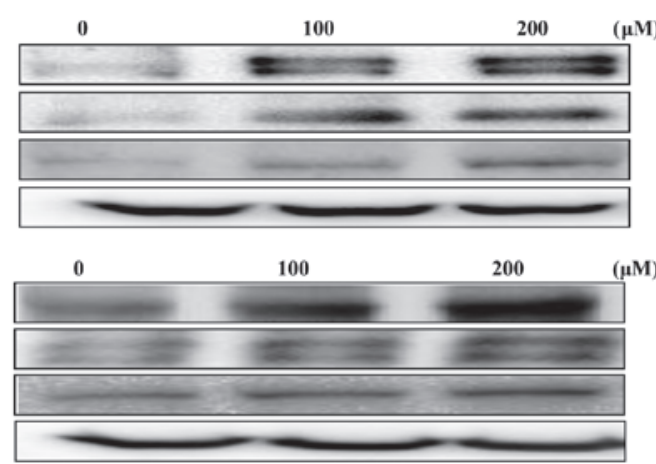

Figure 7. Expressions of caspase-related proteins by (A) hyperoside and (B) rutin on HT-29 human colon cancer cells. Cell lysates were electrophoresed, and cleaved caspases-3, - 8 and - 9 and PARP were detected using immune-blotting analysis. PARP, poly adenosine diphosphate ribose polymerase.

A

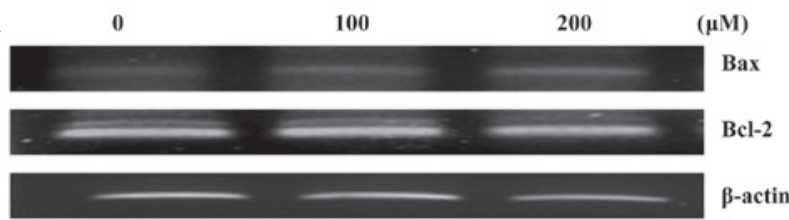

B

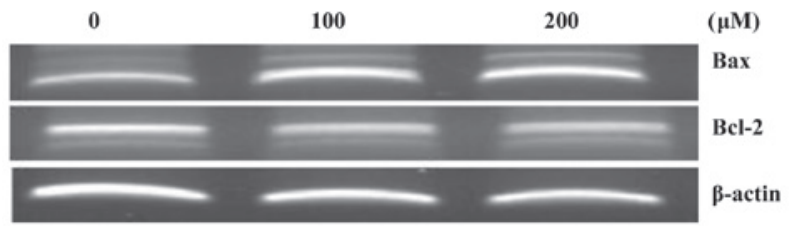

Figure 8. Expression of mRNA levels by (A) hyperoside and (B) rutin in HT-29 human colon cancer cells. Total RNA was electrophoresed, and Bax and $\mathrm{Bcl}-2$ were detected by reverse transcripton-polymerase chain reaction. Bcl-2, B-cell lymphoma 2; Bax, Bcl-2-associated X protein. 
apoptosis, blocking the signals of apoptotic factors (22). As shown in Fig. 6, hyperoside and rutin increased Bax expression but decreased the expression of Bcl-2, each in a dose-dependent manner. Also, a densitometric analysis of the bands showed that hyperoside and rutin caused a dose-dependent increased the Bax/Bcl-2 ratio (Fig. 6C).

Effects on caspase expression. The disruption of the mitochondrial plasma membrane by hyperoside and rutin was followed by the activation of the cleaved caspases-3, 8 and 9 and target protein PARP, respectively (Fig. 7). These results, together with the $\mathrm{Bax} / \mathrm{Bcl}-2$ ratio suggested that hyperoside and rutin may induce apoptosis through the regulation of apoptosis-associated protein expression in HT-29 human colon cancer cells.

RT-PCR analysis. RT-PCR analysis was used to examine any alterations in Bax and Bcl-2 expression. During apoptosis, $\mathrm{Bcl}-2$, a negative regulator of apoptosis, prevents mitochondrial membrane pores from opening; however, the positive regulator, Bax, produces the opposite effect. As a result, hyperoside and rutin increased Bax expression, but decreased the expression of Bcl-2 in a concentration-dependent manner (Fig. 8).

\section{Discussion}

Uncontrolled proliferation is a significant biological feature of cancer cells, and the inhibition of cell proliferation may achieve the arrest of tumor growth (27). Colorectal cancer is the second leading cause of cancer-associated mortalities in the Western world (28). Colorectal cancer is hypothesized to arise as a result of the transformation of normal colonic epithelial cells into a colorectal carcinoma, as an adenomatous polyp. Increased understanding of cancer has led to the development of numerous novel anticancer agents and associated natural therapies, a variety of which clinically target the inhibition of cancer cells, but not normal cells; however, numerous anticancer agents are also toxic to normal cells. Therefore, novel agents that are derived from natural sources, which specifically target colorectal cancer but have a decreased toxicity for normal colonic epithelial cells, hold enormous potential (20).

Apoptosis is an extremely important phenomenon due to the maintenance of cellular homeostasis by the regulation of cell division and cell death (29). The mitochondrial-associated pathway is regulated by anti-apoptotic members, including Bcl-2 and Bcl-2-like 1, and pro-apoptotic members, including Bax, Bcl-2-antagonist/killer 1, BH3 interacting domain death agonist, Bcl-2 associated agonist of cell death and Bcl-2-like 11, of the Bcl-2 family. The anti-apoptotic proteins on the outer membranes of the mitochondria maintain the integrity of the mitochondria, through inhibiting apoptosis in the presence of various apoptotic stimuli (30). In response to an apoptotic stimulus, the pro-apoptotic proteins reside in the cytosol and translocate to the mitochondria, which leads to the formation of membrane pores at the mitochondrial membranes (31). The data in the present study showed that apoptosis with hyperoside and rutin is associated with the upregulation of Bax protein and the downregulation of $\mathrm{Bcl}-2$ expression, each in a dose dependent manner.

Caspase- 3 is one of the key executioners of apoptosis, and is either partially or totally responsible for the proteolytic cleavage of numerous proteins, including PARP (32). PARP is an important factor that allows cells to maintain viability, but the cleavage of PARP facilitates cellular disassembly and acts as a major marker for caspase-dependent apoptosis (33). The cleaved form of PARP was detected in hyperoside and rutin-treated HT-29 cells. These data indicate that hyperoside and rutin induce apoptosis via the mitochondrial pathway. To the best of our knowledge, the present study is the first to demonstrate the cytotoxic effects of hyperoside and rutin on HT-29 human colon cancer cells, and provides a possible mechanism for this activity. The present study indicates that hyperoside and rutin may be the promising candidates for chemotherapy of colon cancer.

\section{References}

1. Kwon YS, Lee DH, Lee KS and Nam KS: Effects of deep-sea water on inhibition of metastatic regulators expression in human colorectal adenocarcinomas by chitosan oligosaccharide. J Chitin Chitosan 4: 229-234, 2012.

2. Jemal A, Bray F, Center MM, Ferlay J, Ward E and Forman D: Global cancer statistics. CA Cancer J Clin 61: 69-90, 2011.

3. Hur SK, Kim SS, Heo YH, Ahn SM, Lee BG and Lee SK. Effects of the grapevine shoot extract on free radical scavenging activity and inhibition of pro-inflammatory mediator production in RAW264.7 macrophages. Biomol Ther 9: 188-193, 2001.

4. Jemal A, Siegel R, Xu J and Ward E: Cancer statistics, 2010. CA Cancer J Clin 60: 277-300, 2010.

5. Siegel RL, Jemal A and Ward EM: Increase in incidence of colorectal cancer among young men and women in the United States. Cancer Epidemiol Biomarkers Prev 18: 1695-1698, 2009.

6. Møller H, Sandin F, Robinson D, Bray F, Klint S, Linklater KM, Lambert PC, Påhlman L, Holmberg L and Morris E: Colorectal cancer survival in socioeconomic groups in England: Variation is mainly in the short term after diagnosis. Eur J Cancer 48: 46-53, 2012.

7. Kopetz S, Chang GJ, Overman MJ, Eng C, Sargent DJ, Larson DW, Grothey A, Vauthey JN, Nagorney DM and McWilliams RR: Improved survival in metastatic colorectal cancer is associated with adoption of hepatic resection and improved chemotherapy. J Clin Oncol 27: 3677-3683, 2009.

8. Hyun JW and Chung HS: Medicinal plants with cytotoxic and antioxidative activity. In: Recent Progress in Medicinal Plants. Sharma AK, Singh VK, Govil JN and Goyal NK (eds). Vol 12. 1st edition. Studium Press LLC, Houston, TX, pp193-202, 2006.

9. Shen-Miller J, Schopf JW, Harbottle G, Cao RJ, Ouyang S, Zhou Ks, Southon JR and Liu G: Long-living lotus: Germination and soil $\gamma$-irradiation of centuries-old fruits, and cultivation, growth, and phenotypic abnormalities of offspring. Am J Bot 89: 236-247, 2002.

10. Park SH, Ham TS and Han JH: Nutritional contents of beverage from lotus root and evaluation of its physiological function in aorta relation. Kor J Ori Med Physiol Pathol 19: 490-494, 2005.

11. Jung HA, Kim JE, Chung HY and Choi JS: Antioxidant principles of Nelumbo nucifera stamens. Arch Pharm Res 26: 279-285, 2003.

12. Li S, Zhang Z, Cain A, Wang B, Long M and Taylor J: Antifungal activity of camptothecin, trifolin, and hyperoside isolated from Camptotheca acuminata. J Agric Food Chem 53: 32-37, 2005.

13. Kao ES, Wang CJ, Lin WL, Yin YF, Wang CP and Tseng TH: Anti-inflammatory potential of flavonoid contents from dried fruit of Crataegus pinnatifida in vitro and in vivo. J Agric Food Chem 53: 430-436, 2005.

14. Choi JH, Kim DW, Yun N, Choi JS, Islam MN, Kim YS and Lee SM: Protective effects of hyperoside against carbon tetrachloride-induced liver damage in mice. J Nat Prod 74: 1055-1060, 2011.

15. Xue YL, Miyakawa T, Hayashi Y, Okamoto K, Hu F, Mitani N, Furihata K, Sawano Y and Tanokura M: Isolation and tyrosinase inhibitory effects of polyphenols from the leaves of persimmon, Diospyros kaki. J Agric Food Chem 59: 6011-6017, 2011

16. Le Gall G, DuPont MS, Mellon FA, Davis AL, Collins GJ, Verhoeyen ME and Colquhoun IJ: Characterization and content of flavonoid glycosides in genetically modified tomato (Lycopersicon esculentum) fruits. J Agric Food Chem 51: 2438-2446, 2003. 
17. Fattouch S, Caboni P, Coroneo V, Tuberoso CI, Angioni A, Dessi S, Marzouki N and Cabras P: Antimicrobial activity of Tunisian quince (Cydonia oblonga Miller) pulp and peel polyphenolic extracts. J Agric Food Chem 55: 963-969, 2007.

18. Shin SW, Lee Y, Moon SR, Koo IH, Hong H, Shin E, Lee M, Park J and Chung HS: Identification of secondary metabolites with antioxidant and antimicrobial activities from Artemisia iwayomogi and Chrysanthemum zawadskii. J Kor Soc Appl Biol Chem 53: 716-723, 2010.

19. Guon TE and Chung HS: Effects of Nelumbo nucifera root extract on proliferation and apoptosis in HT-29 human colon cancer cells. J East Asian Soc Diet Life 24: 20-27, 2014.

20. Ryu MJ and Chung HS: [10]-Gingerol induces mitochondrial apoptosis through activation of MAPK pathway in HCT116 human colon cancer cells. In Vitro Cell Dev Biol Anim 51: 92-101, 2015.

21. Shin HJ, Lee SY, Kim JS, Lee S, Choi RJ, Chung HS, Kim YS and Kang SS: Sesquiterpenes and other constituents from Dendranthema zawadskii var. latilobum. Chem Pharm Bull (Tokyo) 60: 306-314, 2012.

22. Ryu MJ, Kim AD, Kang KA, Chung HS, Kim HS, Suh IS, Chang WY and Hyun JW: The green algae Ulva fasciata Delile extract induces apoptotic cell death in human colon cancer cells. In Vitro Cell Dev Biol Anim 49: 74-81, 2013.

23. Kang KA, Lee JH, Zhang R, Piao MJ, Chung HS and Hyun JW: Oryzadine, a new alkaloid of Oryza sativa cv. Heugjinjubyeo, attenuates oxidative stress-induced cell damage via a radical scavenging effect. Food Chem 119: 1135-1142, 2010.

24. Carmichael J, DeGraff WG, Gazdar AF, Minna JD and Mitchell JB: Evaluation of a tetrazolium-based semiautomated colorimetric assay: Assessment of chemosensitivity testing. Cancer Res 47: 936-942, 1987.
25. Gschwind M and Huber G: Apoptotic cell death induced by $\beta$-amyloid 1-42 peptide is cell type dependent. J Neurochem 65: 292-300, 1995

26. Chung HS, Chang LC, Lee SK, Shamon LA, van Breemen RB, Mehta RG, Farnsworth NR, Pezzuto JM and Kinghorn AD: Flavonoid constituents of Chorizanthe diffusa with potential cancer chemopreventive activity. J Agric Food Chem 47: 36-41, 1999.

27. Liu T, Song Y, Chen H, Pan S and Sun X: Matrine inhibits proliferation and induces apoptosis of pancreatic cancer cells in vitro and in vivo. Biol Pharm Bull 33: 1740-1745, 2010.

28. Strickland L, Letson GD and Muro-Cacho CA: Gastrointestinal stromal tumors. Cancer Control 8: 252-261, 2001.

29. Bold RJ, Termuhlen PM and McConkey DJ: Apoptosis, cancer and cancer therapy. Surg Oncol 6: 133-142, 1997.

30. Nagappan A, Park KI, Park HS, Kim JA, Hong GE, Kang SR, Lee H, Kim EH, Lee WS, Won CK and Kim GS: Vitamin C induces apoptosis in AGS cells by down-regulation of 14-3-3o via a mitochondrial dependent pathway. Food Chem 135: 1920-1928, 2012.

31. Cory S and Adams JM: The Bcl2 family: Regulators of the cellular life-or-death switch. Nat Rev Cancer 2: 647-656, 2002.

32. Kim KN, Ham YM, Moon JY, Kim MJ, Jung YH, Jeon YJ, Lee NH, Kang N, Yang HM, Kim D and Hyun CG: Acanthoic acid induces cell apoptosis through activation of the p38 MAPK pathway in HL-60 human promyelocytic leukaemia. Food Chem 135: 2112-2117, 2012.

33. Oliver FJ, de la Rubia G, Rolli V, Ruiz-Ruiz MC, de Murcia G and Murcia JM: Importance of poly(ADP-ribose) polymerase and its cleavage in apoptosis. Lesson from an uncleavable mutant. J Biol Chem 273: 33533-33539, 1998. 